\title{
Helicobacter salomonis sp. nov., a Canine Gastric Helicobacter sp. Related to Helicobacter felis and Helicobacter bizzozeronii
}

\author{
KATRI JALAVA, ${ }^{1 *}$ M. KAARTINEN, ${ }^{2}$ M. UTRIAINEN,${ }^{1}$ I. HAPPONEN, ${ }^{3}$ AND M.-L. HÄNNINEN ${ }^{1}$ \\ Department of Food and Environmental Hygiene ${ }^{1}$ and Department of Clinical Sciences, ${ }^{3}$ \\ Faculty of Veterinary Medicine, and Faculty of Medicine, Haartman Institute, ${ }^{2}$ \\ University of Helsinki, FIN-00014 Helsinki University, Finland
}

\begin{abstract}
During a study of the prevalence and distribution of gastric helicobacters in domestic pets, a novel group of Helicobacter-like organisms were identified. These "Helicobacter group 2" strains were initially distinguished from the species Helicobacter felis and Helicobacter bizzozeronii by their cellular morphology and the type of motility exhibited. Bacterial cells were only slightly spiral, 5 to $7 \mu \mathrm{m}$ long, and 0.8 to $1.2 \mu \mathrm{m}$ wide and showed an unusual slow wavelike motion. Each cell had tufts of sheathed flagella at one or both ends. Phylogenetic analysis by $16 \mathrm{~S}$ ribosomal DNA sequence comparison revealed that $\boldsymbol{H}$. felis, $\mathrm{H}$. bizzozeronii, "Gastrospirillum hominis" 2, and the new group of helicobacters formed a distinct cluster with intraspecies similarity values of more than $98 \%$. These taxa were clearly separated from all other known Helicobacter species. Dot blot DNA-DNA hybridization studies indicated that the Helicobacter group 2 strains are genetically homogeneous and distinct from other canine and feline gastric helicobacters. Quantitative DNA-DNA hybridization experiments showed that Helicobacter group 2 strains exhibit $>90 \%$ DNA homology to each other, but $<39 \%$ homology to the phylogenetically related taxa $\mathrm{H}$. felis and $\mathrm{H}$. bizzozeronii. We propose the name Helicobacter salomonis for the novel Helicobacter group 2 strains. The type strain is $H$. salomonis Inkinen (= CCUG 37845 ).
\end{abstract}

Since the end of the 19th century, spiral organisms have been observed in the gastric mucosa of both dogs and cats (29, 31). In 1970, Lockard and Boler (22) suggested that three morphologically distinct bacteria could be observed in the canine gastric mucosa, although these bacteria were believed to represent different stages of movement of the same organism (22). Further study of these bacteria was impaired by the lack of suitable methods of culture. However, interest in gastric spiral bacteria increased with the isolation of Helicobacter pylori (36) and the consequent realization of its clinical and economic importance. This interest, combined with the need for a suitable animal model for $H$. pylori infection, led to intense research concerning the presence of similar bacteria in other animal species. As a consequence, there has been a rapid expansion of the number of Helicobacter spp. described. At present, 16 Helicobacter species isolated from humans and different animals have been named $(7,23,24)$.

The first canine gastric Helicobacter sp. isolated in vitro was Helicobacter felis, a large, tightly spiral organism with fibrils wrapped around its cell body (21). A similar organism that lacks periplasmic fibrils is also known to be common in dogs and cats $(12,14,17,21)$. Recently, a group of organisms showing this morphology has been cultured from dogs and named Helicobacter bizzozeronii (12). Spiral bacteria ultrastructurally similar to the latter species have been observed in human, pig, and lemur gastric mucosa and provisionally assigned to the genus "Gastrospirillum" (4, 16, 28, 32). However, the name "Helicobacter heilmannii" has been proposed for the human organism, although this name does not distinguish from the two phylogenetically divergent variants that have been identified (32). A culture of a human isolate resembling " $H$. heilmannii" has been described recently (1). Another organism, which

\footnotetext{
* Corresponding author. Mailing address: Department of Food and Environmental Hygiene, Faculty of Veterinary Medicine, University of Helsinki, P.O. Box 57, FIN-00014 Helsinki University, Finland. Phone: 358-9-70849705. Fax: 358-9-70849718. E-mail: Katri.Jalava@Helsinki .fi.
}

is more cylindrical and has numerous filaments around the cell body, has also been seen in canine gastric mucosa (22). This organism resembles "Flexispira rappini," a Helicobacter-like organism isolated from aborted ovine fetuses (20) and human diarrheal samples (2).

On the basis of DNA-rRNA hybridization data, the genus Helicobacter belongs to rRNA homology group III of rRNA superfamily VI (35). 16S rRNA sequence comparisons have shown that "F. rappini" and "Gastrospirillum" strains are closely related to Helicobacter species (26), with the gastrospirilla forming a discrete phylogenetic cluster within the genus (32).

During a study of the prevalence and species distribution of canine gastric helicobacters, we isolated strains (initially referred to as "Helicobacter group 2") that differed in morphology and in motility characteristics from $H$. felis and $H$. bizzozeronii. We present here phenotypic, genotypic, and phylogenetic data showing that Helicobacter group 2 is a new species which is closely related to other canine gastric helicobacters. The name Helicobacter salomonis is proposed for this taxon.

\section{MATERIALS AND METHODS}

Isolation. Helicobacters were isolated from biopsy samples from healthy pet dogs and adult experimental beagle dogs at the Faculty of Veterinary Medicine. Biopsy, bacterial culture, and primary identification procedures were as described previously $(11,12)$. All of the spiral bacteria isolated were stored in sterile skim milk supplemented with $20 \%$ glycerol at $-70^{\circ} \mathrm{C}$. The Helicobacter group 2 strains and other type and reference strains used in this study are shown in Table 1.

Gross morphology and motility. Giemsa staining was used to detect the organisms from gastric mucosal brush cytology samples as described previously (13). Gram staining was used to visualize the morphology of the cultured organisms. To confirm that the organism isolated belonged to putative Helicobacter group 2, a drop of culture was placed onto a slide and covered with a coverslip, and motility was observed by using an oil immersion method and a light microscope.

Transmission electron microscopy. Bacterial cells were resuspended in physiological $\mathrm{NaCl}$, and a turbid suspension was stained with $1 \%$ phosphotungstic acid and examined with a JEOL model 1200 EX electron microscope, as described previously (12)

Biochemical and tolerance tests. Commonly used phenotypic tests recommended by Ursing et al. (34) for the description of new Campylobacter species, by Goodwin and Armstrong (9) for studies of $H$. pylori, and by Hänninen et al. (12) for studies of $H$. bizzozeronii were used for characterization. The strains were 
TABLE 1. Bacterial strains

\begin{tabular}{|c|c|c|c|c|}
\hline Taxon & $\operatorname{Strain}(\mathrm{s})^{a}$ & Sender ${ }^{b}$ & Source & $\begin{array}{l}\text { Nucleotide sequence } \\
\text { accession no. }\end{array}$ \\
\hline H. salomonis isolate 1 & Elviira I & & Canine gastric mucosa & \\
\hline H. salomonis isolate 2 & Elviira II & & Canine gastric mucosa & \\
\hline H. salomonis isolate 3 & Alma & & Canine gastric mucosa & \\
\hline H. salomonis isolate 4 & 06A (= CCUG 37848) & & Canine gastric mucosa & Y09405 \\
\hline H. salomonis & Vilho & & Canine gastric mucosa & \\
\hline H. salomonis & Mini & & Canine gastric mucosa & \\
\hline H. salomonis & Inkinen $^{\mathrm{T}}\left(=\right.$ CCUG $\left.37845^{\mathrm{T}}\right)$ & & Canine gastric mucosa & U89351 \\
\hline H. salomonis & Ko.K. III & & Canine gastric mucosa & \\
\hline "F. rappini" & ATCC $43966^{c}$ & & Aborted sheep fetus and liver & M88137 \\
\hline " $F$. rappini" & Hilli & & Canine gastric mucosa & \\
\hline "G. hominis" 1 & Unculturable $^{c}$ & & Human gastric mucosa & L10079 \\
\hline "G. hominis" 2 & Unculturable $^{c}$ & & Human gastric mucosa & L10080 \\
\hline H. acinonyx & CCUG $29263^{\mathrm{T}}\left(=\right.$ ATCC $\left.51101^{\mathrm{T}}\right)$ & CCUG & Cheetah gastric mucosa & M88148 \\
\hline H. bilis & ATCC $51630^{\mathrm{Tc}}$ & & Murine liver & U18766 \\
\hline H. bizzozeronii & Storkis $^{\mathrm{T}}\left(=\right.$ CCUG $\left.35545^{\mathrm{T}}\right)$ & & Canine gastric mucosa & Y09404 \\
\hline H. bizzozeronii & $14(=$ CCUG 35046$)$ & & Canine gastric mucosa & \\
\hline H. bizzozeronii & Wiberg & & Canine gastric mucosa & \\
\hline H. bizzozeronii & $5 \mathrm{~F}$ & & Canine gastric mucosa & \\
\hline H. bizzozeronii & 10 & & Canine gastric mucosa & \\
\hline H. bizzozeronii & $12 \mathrm{~A}$ & & Canine gastric mucosa & \\
\hline H. canis & CCUG $12739^{\mathrm{T}}$ & CCUG & Canine feces & L13464 \\
\hline H. cinaedi & ATCC $35683^{\mathrm{Tc}}$ & & Human feces & M88150 \\
\hline H. felis & $\operatorname{CS}^{\mathrm{T}}\left(=\operatorname{ATCC} 49179^{\mathrm{T}}\right)$ & O'Rourke & Feline gastric mucosa & M57398 \\
\hline H. felis & DS3 & O'Rourke & Canine gastric mucosa & M37643 \\
\hline H. felis & DS4 (= CCUG 28540) & CCUG & Canine gastric mucosa & \\
\hline H. felis & $1602(=\operatorname{Dog} 1)^{c}$ & Eaton & Canine gastric mucosa & U51870 \\
\hline H. felis & $2301(=\operatorname{Dog} 2=\operatorname{CCUG} 37850)^{c}$ & Eaton & Canine gastric mucosa & U51871 \\
\hline H. felis & $\operatorname{Dog} 7,(=\operatorname{Dog} 3)$ & Eaton & Canine gastric mucosa & U51872 \\
\hline H. fennelliae & ATCC $35684^{\mathrm{Tc}}$ & & Human feces & M88154 \\
\hline H. hepaticus & ATCC $51448^{\mathrm{Tc}}$ & & Murine liver & U07574 \\
\hline H. mustelae & ATCC $43772^{\mathrm{T}}$ & ATCC & Ferret gastric mucosa & M35048 \\
\hline H. muridarum & ATCC $49282^{\mathrm{Tc}}$ & & Murine intestinal mucosa & M80205 \\
\hline H. nemestrinae & ATCC $49396^{\text {Tc }}$ & & Macaque gastric mucosa & X67854 \\
\hline H. pametensis & CCUG $29255^{\mathrm{T} c}$ & & Tern feces & M88147 \\
\hline H. pullorum & NCTC $12824^{\mathrm{T} c}$ & & Broiler chicken cecum & L36141 \\
\hline H. pylori & Tх30a (= ATCC 51932) & ATCC & Human gastric mucosa & \\
\hline H. pylori & ATCC $43504^{\mathrm{T} c}$ & & Human gastric mucosa & M88157 \\
\hline H. trogontum & ATCC $700114^{\mathrm{T} c}$ & & Rat colon mucosa & U65103 \\
\hline
\end{tabular}

${ }^{a}$ ATCC, American Type Culture Collection, Rockville, Md.; CCUG, Culture Collection, Department of Clinical Bacteriology, University of Göteborg, Göteborg, Sweden; Eaton, K. A. Eaton, Department of Veterinary Pathobiology, Ohio State University, Columbus; O'Rourke, J. L. O'Rourke, School of Microbiology and Immunology, University of New South Wales, Sydney, Australia.

${ }^{b}$ Our isolate unless indicated otherwise.

${ }^{c}$ Only 16S rRNA sequence data were used in this study.

first tested for oxidase, catalase (3\% hydrogen peroxide), rapid urease, and hippurate hydrolysis reactions. All strains were also tested by using API Campy test strips (Biomerieux SA, Marcy l'Etoile, France) and Rosco diagnostic tablets (Rosco Diagnostica, Taastrup, Denmark). These tests included tests for urease nitrate reductase; indoxyl acetate hydrolysis; hippurate hydrolysis; triphenyltetrazolium chloride (TTC) reduction; gamma-glutamyl transpeptidase; pyrrolidonyl, L-arginine, and L-aspartate arylamidases; and alkaline phosphatase. DNase production was also tested (10).

The following tolerance tests were done on brucella (Oxoid, Basingstoke, United Kingdom) blood agar containing $1 \%$ glycine, $1 \%$ ox bile (Difco Laboratories, Detroit, Mich.), and $2.5 \% \mathrm{NaCl}$. Antibiotic sensitivity was tested on brucella blood agar supplemented with nalidixic acid (30- $\mu$ g disks; AB Biodisk, Solna, Sweden), cephalothin ( $30-\mu \mathrm{g}$ disks; AB Biodisk), metronidazole (50- $\mu \mathrm{g}$ disks; Rosco), and cefoperazone (60- $\mu$ g disks; Rosco). All growth and tolerance tests were incubated for up to 7 days in a microaerobic atmosphere at $37^{\circ} \mathrm{C}$

Growth conditions. Growth of the organisms was tested on brain heart infusion (BHI) (Oxoid) blood agar, brucella (Oxoid) blood agar, nutrient (Oxoid) blood agar, and Mueller-Hinton (Oxoid) blood agar. Growth at 25, 30, 37, 40, and $42^{\circ} \mathrm{C}$ was tested on brucella blood agar. Growth in liquid media was tested by using brucella broth (Oxoid) containing 5\% horse serum and $0.1 \%$ soluble starch. A shallow medium was used, and during incubation the media were continuously shaken at $100 \mathrm{rpm}$. The cultures were incubated for 7 days in a microaerobic atmosphere at $37^{\circ} \mathrm{C}$

Amplification of 16S ribosomal DNA by PCR and purification of the PCR product. The 16S rRNA gene sequence of selected canine helicobacter strains (see below for details) was obtained from genomic bacterial DNA by PCR amplification with two primers, biotinylated primer HY-2B (pGCCTAATACA TGCAAGTCGAACG; anneals to positions 45 to 67 of Escherichia coli $16 \mathrm{~S}$ rRNA) and primer A-2 (pCGGTTACCTTGTTACGACTTC; positions 1524 to 1541 ). The PCR conditions used have been described previously (38), and purification of single-stranded DNA from biotinylated PCR product was performed as described previously (38).

Sequencing. The 16S rRNA gene sequences of Helicobacter group 2 strain 06A and $H$. bizzozeronii CCUG $35545^{\mathrm{T}}$ were determined as follows. Nucleotide sequences were determined by using Sanger's dideoxy method and Sequenase 2.0R polymerase (Amersham, Arlington Heights, III.) according to the manufacturer's recommendations. To sequence the partial $16 \mathrm{~S}$ rRNA gene sequences directly from PCR templates, we used primer A-2 together with the following five additional primers: R1 (pCTGCTGGCACGGAGTTAGCC; positions 505 to 525), R339 (pACTGCTGCCTCCCGTAGGAG; positions 339 to 358), R4 (pCC AGGGTATGTAATCCTCTT; positions 781 to 800), R5 (pGTGACGACAGC CATCAGCA; positions 1049 to 1068), and R6 (pTGTGACGGGCGGTGTG TACA; positions 1391 to 1410). Ten milliliters of avidin-coated Pandex beads (IDEXX, Westbrook, France) with attached single-stranded PCR product was used as the template in the dideoxy sequencing reactions. The 16S rRNA gene sequence of Helicobacter group 2 strain Inkinen ${ }^{T}$ was determined by PCR amplification of the 16S rRNA gene and cycle sequencing as described previously (6).

Phylogenetic analysis. The 16S rRNA gene sequences were entered into RNA, a program for analysis of 16S rRNA data in Microsoft Quickbasic for use with IBM PC-compatible computers, and aligned as previously described (25). The database used contains approximately 100 Helicobacter, Wolinella, Arcobacter, 
and Campylobacter sequences and more than 900 sequences for other bacteria Similarity matrices were constructed from aligned sequences by using only those base positions for which $90 \%$ of the strains had data and were corrected for multiple hase changes by the method of Jukes and Cantor (19). Phylogenetic trees were constructed by the neighbor-joining method (30). The nucleotide sequence accession numbers for the strains examined in this study are listed in Table 1 .

DNA isolation. To obtain sufficient quantities of DNA for DNA-DNA hybridizations, a few hundred plates of each strain were cultured under the condition described previously $(11,12)$. DNA was isolated by the method of Pitcher et al (27), with modifications designed to remove the RNA and proteins. RNase and proteinase $\mathrm{K}$ treatments were performed after dissolution in TE $(10 \mathrm{mM}$ Tris$\mathrm{HCl}, 1 \mathrm{mM}$ EDTA), and the DNA was reprecipitated as in the first phase.

Dot blot DNA-DNA hybridizations. Dot blot DNA-DNA hybridizations were performed by dot blot assay on nylon membranes (Micron Separations, Inc. Westborough, Mass.) by using a vacuum-blotting apparatus (Pharmacia LKB Biotechnology, Uppsala, Sweden); 50-, 5-, and 0.5-ng aliquots of diluted chromosomal DNA were added to the nylon membranes. The type and reference strains used were $H$. felis $\mathrm{CS}^{\mathbf{T}}$, DS 3 , and DS4, $H$ bizzozeronii CCUG $35545^{\mathbf{T}}$, CCUG 35046, Wiberg, 5F, 10, and 12A, H. pylori $\mathrm{Tx} 30 \mathrm{a}$, Helicobacter mustelae ATCC $43772^{\mathrm{T}}$, Helicobacter acinonyx CCUG $29263^{\mathrm{T}}$, and " $F$. rappini" Hilli (Table 1). The probes used were genomic DNAs from $H$. bizzozeronii CCUG $35545^{\mathrm{T}}$ $H$. salomonis Elviira II, and $H$. felis $\mathrm{CS}^{\mathrm{T}}$ and DS3 (Table 1 ). Hybridizations were performed as described previously (12), except that three different temperatures $\left(58,68\right.$, and $\left.74^{\circ} \mathrm{C}\right)$ were used. The tests were repeated three times.

Optical DNA-DNA hybridization. Optical DNA-DNA hybridization was performed essentially by the initial reassociation method of De Ley (3) with a DNA concentration of $35 \mu \mathrm{g} / \mathrm{ml}$ as recommended by Huss et al. (18). The DNA samples were adjusted to a concentration of approximately $300 \mu \mathrm{g} / \mathrm{ml}$ by adding $20 \times \mathrm{SSC}(1 \times \mathrm{SSC}$ is $0.15 \mathrm{M} \mathrm{NaCl}$ plus $0.015 \mathrm{M}$ sodium citrate $)$ to the initial $0.1 \times$ SSC to reach a concentration of approximately $2 \times$ SSC. DNA was subsequently fragmented by sonication and dialyzed against $2 \times$ SSC overnight at $4^{\circ} \mathrm{C}$. The samples were stored at $-20^{\circ} \mathrm{C}$ before measurement. Hybridization was performed with a Lambda 11 spectrophotometer by using a type PTP 6 heating element (Perkin-Elmer, Ueberlingen, Germany) and Winlab and Templab software (Perkin-Elmer). Renaturation of the DNA was performed as recommended previously (15). The optimal reassociation temperature $\left(69^{\circ} \mathrm{C}\right)$ was used, as recommended by Gillis et al. (8). The degree of binding was calculated by using the formula recommended by De Ley (3). Hybridizations were performed at least twice except where stated otherwise.

\section{RESULTS}

Culture. Five strains were isolated from corpus biopsies of dogs. One of the strains was represented by four isolates. Two of these isolates were from two experimental beagle bitches (bitches A and E) from the same supplier of experimental animals; the other two isolates of this strain were subsequently isolated from the offspring of these bitches. Ribotyping of all of these isolates with three different restriction enzymes suggested that they represented the same bacterial clone (data not shown). The sources and designations of the strains are shown in Table 1. Primary isolation of Helicobacter group 2 strains from biopsy material usually occurred after 3 to 6 days of incubation, and the growth appeared as a thin, nonhemolytic spreading film. In subcultures, bacterial growth was more rapid and profuse and was normally observed within 2 days. All strains showed some growth in brucella broth supplemented with horse serum. As the cultures aged, coccal forms were seen.

Gross morphology and motility. In Giemsa-stained preparations of direct mucosal brush cytology samples, Helicobacter group 2 cells were shorter and less spiral than $H$. bizzozeronii and $H$. felis cells in comparable samples (Fig. 1). Gram-stained Helicobacter group 2 cells were rather thick, and the cell body was only slightly spiral. The motility of the strains as determined by light microscopy was rather slow and wavy. By contrast, the motility of $H$. felis and $H$. bizzozeronii was rapid, and movement was attained by means of a vigorous corkscrew-like action. The motility properties were observed in 48-h cultures.

Ultrastructure. As determined by transmission electron microscopy, Helicobacter group 2 cells were loosely helical or wavy rods, 5 to $7 \mu \mathrm{m}$ long and 0.8 to $1.2 \mu \mathrm{m}$ wide. They had multiple sheathed flagella at one or both ends, and no fibrils

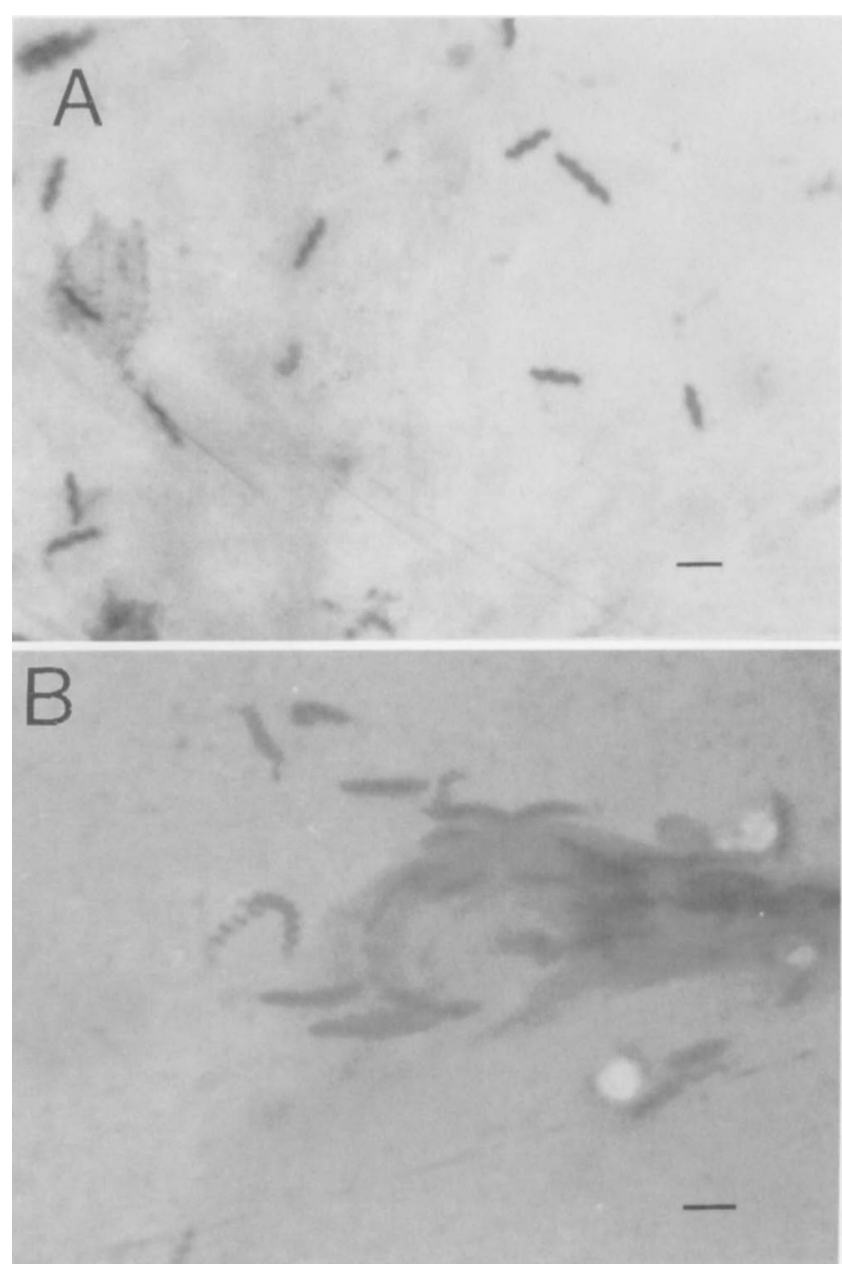

FIG. 1. Giemsa-stained brush cytology samples from the gastric mucosae of a beagle puppy naturally infected with $H$. salomonis 06A (= CCUG 37848) (A) and a beagle puppy infected intentionally with $H$. bizzozeronii Storkis $^{\mathrm{T}}(=\mathrm{CCUG}$ $35545^{\mathrm{T}}$ ) (B). Note the thicker appearance and less helical cell body of $H$. salomonis. Bar $=5 \mu \mathrm{m}$.

were seen (Fig. 2). The cell bodies of Helicobacter group 2 strains were shorter and thicker than the cell bodies of $H$. bizzozeronii (Fig. 1 and 2 and Table 2). The cell body of Helicobacter group 2 was markedly less helical than that of $H$. felis or $H$. bizzozeronii.

Biochemical and tolerance tests. Thirty tests were used to characterize the Helicobacter group 2 isolates. All of the strains were oxidase, catalase, and urease positive and grew on bloodsupplemented BHI, brucella, nutrient, and Mueller-Hinton agar media. The best growth was obtained on BHI and brucella agar media. The strains also grew weakly in brucella broth supplemented with $0.1 \%$ soluble starch and $5 \%$ horse serum. Helicobacter group 2 phenotypically resembled $H$. bizzozeronii and $H$. felis and had similar antibiotic susceptibilities, although the isolates from two dams and their puppies were resistant to metronidazole. Helicobacter group 2 strains could nonetheless be differentiated from both $H$. bizzozeronii and $H$. felis by their ability to hydrolyze indoxyl acetate, by their ability to reduce TCC, and by their inability to grow at temperatures higher than $40^{\circ} \mathrm{C}$. The salient tests that distinguish Helicobacter group 2 from other canine gastric helicobacters are listed in Table 2.

Sequencing and phylogenetic analysis. Approximately $95 \%$ of the 16S rRNA sequence was determined for each of the 


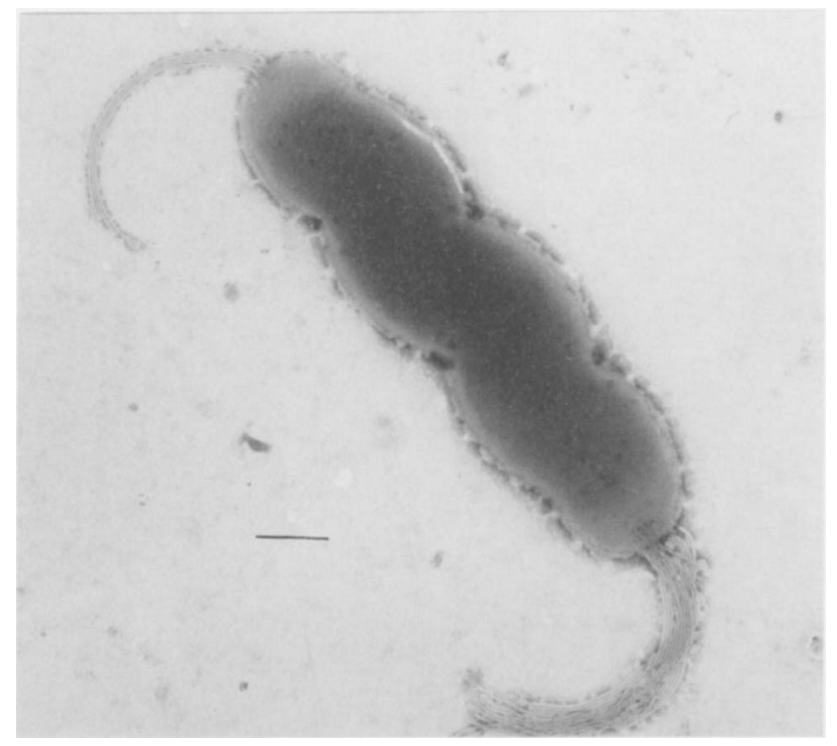

FIG. 2. Transmission electron micrograph of $H$. salomonis. Note the multiple sheathed flagella and the slight loss of spiral morphology compared to Fig. 1A. $\mathrm{Bar}=1 \mu \mathrm{m}$.

Helicobacter strains examined. A similarity matrix based on comparisons of $16 \mathrm{~S}$ rRNA sequences of 24 strains representing 19 Helicobacter species is shown in Table 3. Only those base positions (1,404 positions) for which $90 \%$ of the strains possessed data were included in the similarity calculation. A phylogenetic tree based on this analysis is shown in Fig. 3. This analysis showed that the novel Helicobacter group 2 strains, $H$. felis, $H$. bizzozeronii, and "Gastrospirillum hominis" 2 were highly related and formed a distinct cluster within rRNA homology group III (i.e., the Helicobacter phylogenetic branch) of rRNA superfamily VI.

Dot blot DNA-DNA hybridization. Dot blot DNA-DNA hybridization at $74^{\circ} \mathrm{C}$ revealed that the Helicobacter group 2 probe did not hybridize intensively either with $H$. felis DNA or with $H$. bizzozeronii DNA, but hybridized strongly with DNAs from all of the other Helicobacter group 2 isolates. Similarly, the $H$. bizzozeronii CCUG $35545^{\mathrm{T}}$ probe hybridized with all strains of $H$. bizzozeronii. Both $H$. felis $\mathrm{CS}^{\mathrm{T}}{ }^{\mathrm{T}}$ - and DS3-derived probes hybridized with all $H$. felis strains. The results obtained in experiments performed at 68 and $74^{\circ} \mathrm{C}$ were the same; $58^{\circ} \mathrm{C}$ proved to be less stringent.

Optical DNA-DNA hybridization. The Helicobacter group 2 strains selected for the optical DNA-DNA hybridization experiments gave interstrain DNA reassociation values of more than $90 \%$ (Table 4). The levels of DNA-DNA hybridization between Helicobacter group 2 strains and strains of $H$. felis and H. bizzozeronii were significantly lower (11 to 39\%) (Table 4).

\section{DISCUSSION}

It has been known for a century that the gastric mucosa of dogs, cats, and other species may harbor up to three morphologically different spiral organisms $(10)$, the clinical significance of which has remained unclear $(5,14)$. These bacteria have long been considered to be unculturable (21), and their characterization has been mainly limited to ultrastructural studies. More recently, sequence analysis of the $16 \mathrm{~S}$ rRNA gene has been used (32). The general lack of information about these bacteria has resulted in confusion in their classification and nomenclature. Older literature treats these organisms as spirochetes and spirilla among other things, while using $16 \mathrm{~S}$ rRNA sequence data to classify these bacteria has resulted in

TABLE 2. Characteristics of $H$. salomonis and related gastric helicobacters ${ }^{a}$

\begin{tabular}{|c|c|c|c|c|c|c|}
\hline Characteristic & H. salomonis & H. bizzozeronii & H. felis & H. pylori & H. acinonyx & "F. rappini" \\
\hline Cell length $(\mu \mathrm{m})$ & $5-7$ & $5-10$ & $5-7.5$ & $2.5-5$ & $1.5-2.0$ & $6-15$ \\
\hline Cell width $(\mu \mathrm{m})$ & $0.8-1.2$ & 0.3 & 0.4 & $0.5-1.0$ & 0.3 & $0.5-1.0$ \\
\hline Periplasmic fibrils & - & - & + & - & + & + \\
\hline Location of flagella & Bipolar & Bipolar & Bipolar & Polar & Polar & Bipolar \\
\hline No. of flagella & $10-23$ & $10-20$ & $14-20$ & $4-8$ & $2-5$ & $10-20$ \\
\hline Flagellar sheath & + & + & + & + & + & + \\
\hline Catalase activity & $+(5 / 5)^{b}$ & + & + & + & + & + \\
\hline Oxidase activity & $+(5 / 5)$ & + & + & + & + & + \\
\hline Urease activity (rapid) & $+(5 / 5)$ & + & + & + & + & + \\
\hline Nitrate reduction & $+(5 / 5)$ & + & + & - & - & - \\
\hline Hippurate hydrolysis & $-(0 / 5)$ & - & - & - & - & - \\
\hline Indoxyl acetate hydrolysis & $+(5 / 5)$ & + & - & - & - & + \\
\hline$\gamma$-Glutamyl aminopeptidase & $+(5 / 5)$ & + & + & + & + & + \\
\hline TTC reduction & $+(5 / 5)$ & + & - & + & ND & + \\
\hline Alkaline phosphatase activity & $+(5 / 5)$ & + & + & + & + & + \\
\hline DNase activity & $+(4 / 5)$ & + & + & + & ND & $\mathrm{ND}$ \\
\hline \multicolumn{7}{|l|}{ Growth at: } \\
\hline $25^{\circ} \mathrm{C}$ & $-(0 / 5)$ & - & - & - & - & - \\
\hline $37^{\circ} \mathrm{C}$ & $+(5 / 5)$ & + & + & + & + & + \\
\hline $40^{\circ} \mathrm{C}$ & $(+)(3 / 3)$ & ND & ND & ND & ND & ND \\
\hline $42^{\circ} \mathrm{C}$ & $-(0 / 5)$ & + & - & - & + & - \\
\hline Tolerance to $1 \%$ ox bile & $-(0 / 5)$ & - & - & - & - & - \\
\hline \multicolumn{7}{|l|}{ Susceptibility to: } \\
\hline Nalidixic acid $(30-\mu \mathrm{g}$ disk) & $\mathrm{R}(0 / 5)$ & $\mathrm{R}$ & $\mathrm{R}$ & $\mathrm{R}$ & $\mathrm{R}$ & $\mathrm{S}$ \\
\hline Cephalothin $(30-\mu \mathrm{g}$ disk) & $\mathrm{S}(5 / 5)$ & $\mathrm{S}$ & $\mathrm{S}$ & $\mathrm{S}$ & $\mathrm{R}$ & $\mathrm{S}$ \\
\hline Cefoperazone (60- $\mu \mathrm{g}$ disk) & $\mathrm{S}(5 / 5)$ & $\mathrm{S}$ & $\mathrm{S}$ & $\mathrm{ND}$ & ND & $\mathrm{S}$ \\
\hline Metronidazole $(50-\mu \mathrm{g}$ disk $)$ & $\mathrm{S}(4 / 5)$ & $\mathrm{S}$ & $\mathrm{S}$ & $\mathrm{S}$ & $\mathrm{S}$ & $\mathrm{S}$ \\
\hline
\end{tabular}

${ }_{-}$, negative or not present; +, positive or present; ND, not determined; R, resistant; S, susceptible.

${ }^{b}$ The data in parentheses are the number of strains that have the characteristic indicated/number of strains tested. 


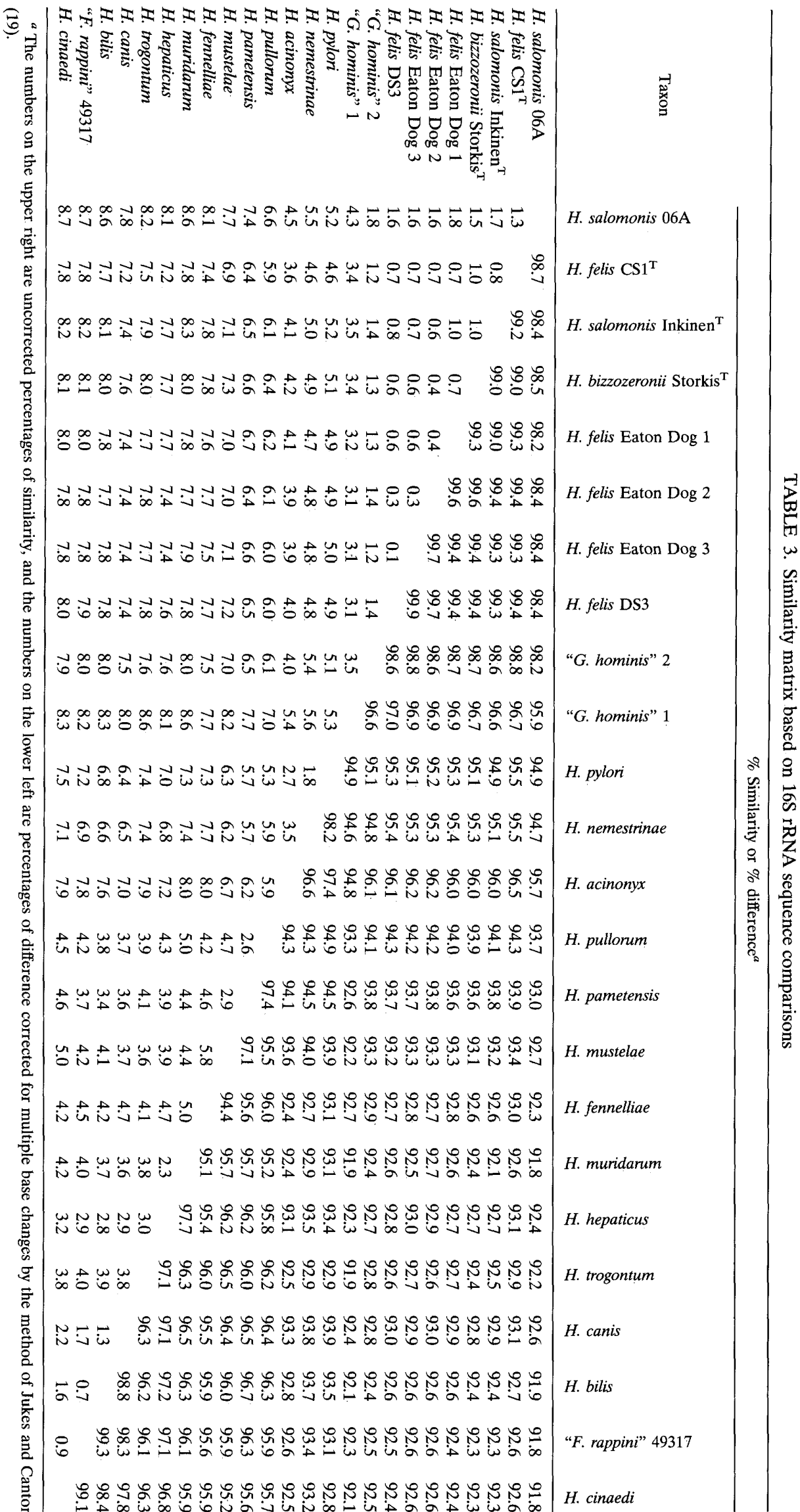




\section{(\% Difference)}

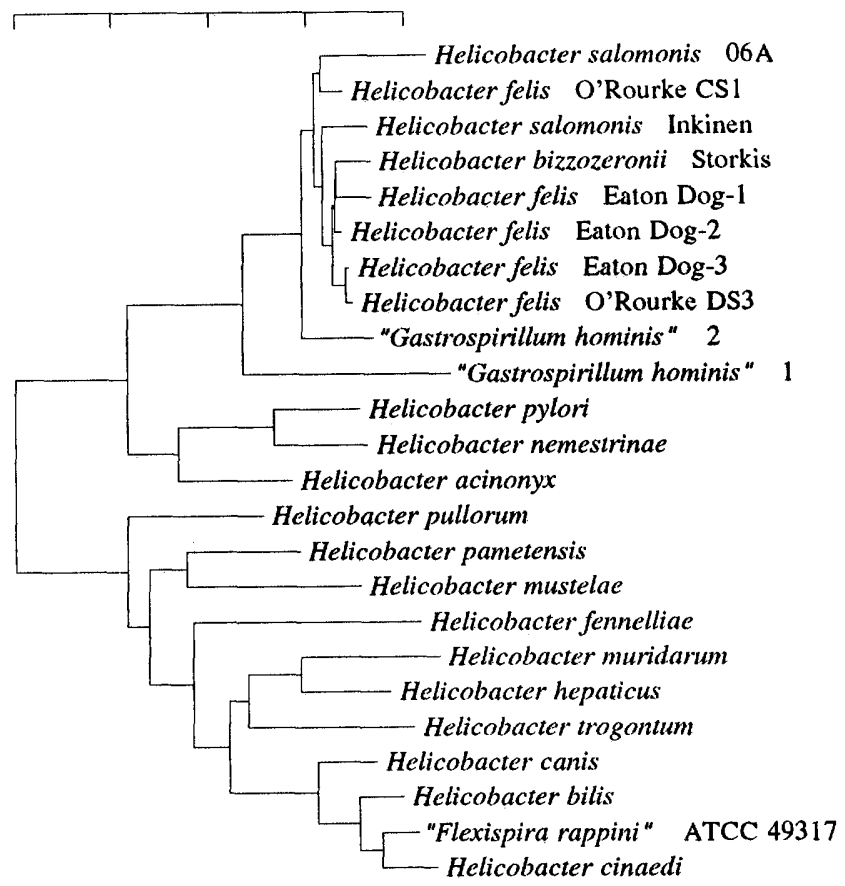

FIG. 3. Phylogenetic tree for 20 strains of Helicobacter species based on $16 \mathrm{~S}$ rRNA sequence similarity. The scale bar represents a $4 \%$ difference in nucleotide sequences as determined by measuring the lengths of the horizontal lines connecting any two species.

different taxonomic problems. For example, sequences purported to represent two distinct species infecting humans ("G. hominis" 1 and "G. hominis" 2) have both been called "H. heilmannii" (32). The only validly described species showing a distinctive spiral ultrastructure similar to the gastrospirilla are $H$. felis (26) and $H$. bizzozeronii (12).

In direct Giemsa-stained preparations of brush cytology samples, Helicobacter group 2 strains were observed to be coiled bacilli. In culture, this morphology altered, and only loosely helical or slightly curved thick forms were seen in Gram-stained bacterial films, in contrast to comparable preparations of $H$. felis and $H$. bizzozeronii, which retained a distinct spiral morphology. In addition, the motility of Helicobacter group 2 strains was wavelike and slow compared with both $H$. felis and $H$. bizzozeronii. This might be due to the less pronounced spiral cell body of Helicobacter group 2; we noted that $H$. felis and $H$. bizzozeronii were able to move in a rapid, screwlike fashion. In electron micrographs, Helicobacter group 2 isolates were less helical and thicker than $H$. bizzozeronii and did not have the periplasmic fibrils that are seen typically in $H$. felis. Indeed, Weber and Schmittdiel (37) may have observed Helicobacter group 2 strains in their investigations of gastric spiral bacteria in dogs, since the organism displayed in Fig. 4 of their paper has a marked resemblance to the organisms which we describe here.

The cultural characteristics of $H$. felis, $H$. bizzozeronii, and Helicobacter group 2 were similar. After primary isolation, H. felis and Helicobacter group 2 showed profuse growth within 2 days, while $H$. bizzozeronii needed 3 to 4 days for visible growth to appear. $H$. bizzozeronii was the only one of these taxa to show some growth at $42^{\circ} \mathrm{C}$. Helicobacter group 2 showed growth in broth media. Conversely, $H$. bizzozeronii did not show any turbidity in broth cultures (12). Both $H$. bizzozeronii and Helicobacter group 2 were able to hydrolyze indoxyl acetate and reduce TTC, unlike $H$. felis. All canine gastric helicobacter cells exhibit coccal transformation as the cultures age.

It should be noted that the gastric mucosa of dogs may be colonized by several Helicobacter species simultaneously. Since the isolation procedures for and cultural characteristics of all canine gastric helicobacters are very similar $(12,21)$, mixed cultures of different Helicobacter species or different strains of the same species may be obtained. All of our strains were isolated during 1994 and 1995. They were all subcultured at least 10 to 20 times. To ascertain the purity of the strains, motility tests and Gram staining were performed after almost every subculture. Visual examination of sodium dodecyl sulfate-polyacrylamide gel electrophoresis protein profiles and ribotyping with three different enzymes were performed on several occasions (data not shown). All of the strains described in this paper remained similar throughout this study. We obtained one known mixed culture of $H$. salomonis and H. bizzozeronii which was omitted from this study.

Recently, on the basis of high 16S rRNA sequence similarity values, Eaton et al. (5) described three $H$. felis organisms without periplasmic fibrils. Their strain Dog 3 exhibited sequence differences of 0.7 and $0.6 \%$ with $H$. felis $C S 1^{\mathrm{T}}$ and DS3, respectively. Our quantitative DNA-DNA hybridization study performed with strain Dog 3 revealed a level of DNA relatedness of $66 \%$ with $H$. felis $\mathrm{CS}^{\mathrm{T}}$. This strain hybridized 12 and $26 \%$ with $H$. bizzozeronii CCUG $35545^{\mathrm{T}}$ and Helicobacter group 2 strain Inkinen ${ }^{\mathrm{T}}$, respectively.

The only cultured isolate of the human gastrospirillum group ("H. heilmannii") has been reported to form small, uniform, translucent colonies similar to those of $H$. pylori in primary isolation preparations after 5 days of incubation (1). None of our canine gastric helicobacters has shown this type of growth. However, a more detailed polyphasic study is necessary to ascertain the relationship of this human isolate to $\mathrm{Hel}$ icobacter group 2 (described here), H. bizzozeronii, $H$. felis, " $G$. hominis" 1, "G. hominis" 2, "Gastrospirillum suis," and "Gastrospirillum lemur."

The 16S rRNA sequences of strains representing $\mathrm{H}$. felis, $\mathrm{H}$. bizzozeronii, and Helicobacter group 2 were 98.2 to $100 \%$ similar to one another, clearly indicating a close phylogenetic relationship. Helicobacter group 2 strain Inkinen ${ }^{T}$ differed from $H$. bizzozeronii, $H$. felis, and " $G$. hominis" 2 by $1.0,0.8$, and $1.4 \%$, respectively. Furthermore, the two sequences Helicobacter group 2 strains differed by $1.7 \%$ from each other. Because of the high degrees of sequence similarity among these Helicobacter species and sequence variability within the species,

TABLE 4. Optical DNA-DNA reassociation values

\begin{tabular}{|c|c|c|c|}
\hline \multirow[b]{2}{*}{ Strain } & \multicolumn{3}{|c|}{$\begin{array}{l}\text { \% Optical DNA-DNA } \\
\text { reassociation with: }\end{array}$} \\
\hline & $\begin{array}{l}\text { H. salo- } \\
\text { monis } \\
\text { Inkinen }^{\mathrm{T}}\end{array}$ & $\begin{array}{c}\text { H. bizzo- } \\
\text { zeronii } \\
\text { Storkis }^{\mathrm{T}}\end{array}$ & $\begin{array}{c}\text { H. felis } \\
\mathrm{CS}^{\mathrm{T}}\end{array}$ \\
\hline H. salomonis Elviira II & 100 & 34 & 34 \\
\hline H. salomonis Mini & 92 & $34^{a}$ & $39^{a}$ \\
\hline H. salomonis Inkinen ${ }^{\mathrm{T}}\left(=\mathrm{CCUG} 37845^{\mathrm{T}}\right)$ & 100 & $11^{a}$ & $38^{a}$ \\
\hline H. bizzozeronii Storkis $^{\mathrm{T}}\left(=\right.$ CCUG $\left.35545^{\mathrm{T}}\right)$ & $11^{a}$ & 100 & 22 \\
\hline H. bizzozeronii 14 (= CCUG 35046) & 23 & 89 & 2 \\
\hline H. bizzozeronii $12 \mathrm{~A}$ & 33 & 74 & 20 \\
\hline H. felis $\operatorname{CS}^{\mathrm{T}}\left(=\operatorname{ATCC} 49179^{\mathrm{T}}\right)$ & 38 & 22 & 100 \\
\hline H. felis DS3 & $37^{a}$ & $30^{a}$ & $79^{a}$ \\
\hline H. felis Dog 3 & 26 & 12 & $66^{a}$ \\
\hline
\end{tabular}

${ }^{a}$ Only one result was obtained. 
$16 S$ rRNA sequence information cannot be used to establish species boundaries (33). The accepted gold standard of DNADNA hybridization was therefore used to delimit species boundaries for the strains in this cluster.

The dot blot DNA-DNA hybridization method was found to be a good screening method which could be used to select strains for the quantitative DNA-DNA reassociation study. Representatives of $H$. felis, $H$. bizzozeronii, and Helicobacter group 2 were confirmed by using the quantitative DNA-DNA reassociation method to identify separate species. Therefore, as determined by a variety of phenotypic and genotypic criteria, Helicobacter group 2 can be shown to be a distinct, novel Helicobacter species, for which we propose the name $H$. salomonis.

Description of Helicobacter salomonis sp. nov. Helicobacter salomonis (sa.lo.mo'nis, L. gen. n. salomonis, of Salomon; in honor of Hugo Salomon, a German scientist who was one of the first workers to describe three morphologically different spiral organisms in canine gastric mucosa). The cells in in vitro cultures are loose spirals that are 0.8 to $1.2 \mu \mathrm{m}$ wide by 5 to 7 $\mu \mathrm{m}$ long. They do not have periplasmic fibrils. In older cultures coccoids predominate. The cells are gram negative and nonsporulating. They are motile by means of tufts of 10 to 23 sheathed flagella at one or both ends of the cell; the movement is slower than that of $H$. felis or $H$. bizzozeronii. Individual colonies are not formed, but cultures grow as spreading films on fresh moist agar media. All strains are oxidase, catalase, and urease positive. They reduce nitrate and TTC, and they are positive in indoxyl acetate, gamma-glutamyl transpeptidase, and alkaline phosphatase tests. They are negative in hippurate hydrolysis, pyrrolidonyl arylamidase, L-arginine arylamidase, and L-aspartate arylamidase tests. Four of the five strains produce DNase. They are resistant to nalidixic acid and are susceptible to cephalothin and cefoperazone. One strain shows resistance to metronidazole. They do not grow on media containing $1 \%$ ox bile, $1 \%$ glycine, or $1.5 \% \mathrm{NaCl}$. They grow at $37^{\circ} \mathrm{C}$, but not at 25 or $42^{\circ} \mathrm{C}$. All of the biochemical and tolerance characteristics are similar to the characteristics of $H$. bizzozeronii, except that one strain of $H$. salomonis is DNase negative and one strain is resistant to metronidazole. The clinical significance of $H$. salomonis is unknown.

Description of the type strain. Strain CCUG 37845 (= Inkinen) is the type strain of $H$. salomonis. This strain conforms to the description given above. It was isolated from a gastric biopsy of a healthy pet dog. An additional strain, strain 06A, has been deposited in the Culture Collection of the University of Göteborg as strain CCUG 37848.

\section{ACKNOWLEDGMENTS}

We thank Urszula Hirvi and Eila Pelkonen for excellent technical assistance. We thank Floyd E. Dewhirst, Department of Molecular Genetics, Forsyth Dental Center, Boston, Mass., for the sequence of $H$. salomonis Inkinen ${ }^{\mathbf{T}}$ and for constructing the homology matrix and phylogenetic tree. For depositing the strains used in this study, we thank Jani O'Rourke (Australia), Enevold Falsen (Sweden), and Kate Eaton (United States). We are very grateful to Stephen L. W. On for English language corrections and useful discussions.

K.J. was supported by a young scientists award from Emil Aaltosen saatio. Mari Utriainen was supported by the Helsinki University 350 Year Foundation.

\section{REFERENCES}

1. Andersen, L. P., A. Nørgaard, S. Holck, J. Blom, and L. Elsborg. 1996. Isolation of a "Helicobacter heilmannii"-like organism from the human stomach. Eur. J. Clin. Microbiol. Infect. Dis. 15:95-96. (Letter.)

2. Archer, J. R., S. Romero, A. E. Ritchie, M. E. Hamacher, B. M. Steiner, J. H.
Bryner, and R. F. Schell. 1988. Characterization of an unclassified microaerophilic bacterium associated with gastroenteritis. J. Clin. Microbiol 26:101-105.

3. De Ley, J. 1970. Reexamination of the association between melting point, buoyant density, and chemical base composition of deoxyribonucleic acid. $\mathrm{J}$. Bacteriol. 101:738-754.

4. Dent, J. C., C. A. M. McNulty, J. C. Uff, S. P. Wilkinson, and M. W. L. Gear. 1987. Spiral organisms in the gastric antrum. Lancet ii:96. (Letter.)

5. Eaton, K. A., F. E. Dewhirst, B. J. Paster, N. Tzellas, B. E. Coleman, J. Paola, and R. Sherding. 1996. Prevalence and varieties of Helicobacter species in dogs from random sources and pet dogs: animal and public health implications. J. Clin. Microbiol. 34:3165-3170.

6. Fox, J. G., L. L. Yan, F. E. Dewhirst, B. J. Paster, B. Shames, J. C. Murphy, A. Hayward, J. C. Belcher, and E. N. Mendes. 1995. Helicobacter bilis sp. nov., a novel Helicobacter species isolated from bile, livers, and intestines of aged, inbred mice. J. Clin. Microbiol. 33:445-454.

7. Franklin, C. L., C. S. Beckwith, R. S. Livingston, L. K. Riley, S. V. Gibson, C. L. Besch-Williford, and R. R. Hook, Jr. 1996. Isolation of a novel Helicobacter species, Helicobacter cholecystus sp. nov., from the gall bladders of Syrian hamsters with cholangiofibrosis and centrilobular pancreatitis. J. Clin. Microbiol. 34:2952-2958.

8. Gillis, M., J. De Ley, and M. De Cleene. 1970. The determination of molecular weight of bacterial genome DNA from renaturation rates. Eur. J. Biochem. 12:143-153.

9. Goodwin, C. S., and J. A. Armstrong. 1990. Microbiological aspects of $\mathrm{Hel}$ icobacter pylori (Campylobacter pylori). Eur. J. Clin. Microbiol. Infect. Dis. 9:1-13

10. Hänninen, M.-L. 1989. Rapid method for the detection of DNase of campylobacters. J. Clin. Microbiol. 27:2118-2119.

11. Hänninen, M.-L., K. Jalava, S. Saari, I. Happonen, and E. Westermarck. 1995. Culture of "Gastrospirillum" from gastric biopsies of dogs. Eur. J. Clin. Microbiol. Infect. Dis. 14:145. (Letter.)

12. Hänninen, M.-L., I. Happonen, S. Saari, and K. Jalava. 1996. Culture and characteristics of Helicobacter bizzozeronii, a new canine gastric Helicobacter sp. Int. J. Syst. Bacteriol. 46:160-166.

13. Happonen, I., S. Saari, L. Castren, O. Tyni, M.-L. Hanninen, and E. Westermarck. 1996. Comparison of diagnostic methods for detecting gastric Helicobacter-like organisms in dogs and cats. J. Comp. Pathol 115:117-127.

14. Happonen, I., S. Saari, L. Castren, O. Tyni, M.-L. Hanninen, and E. Westermarck. 1996. Occurrence and topographical mapping of gastric Helicobacter-like organisms and their association with histological changes in apparently healthy dogs and cats. J. Vet. Med. Assoc. 43:305-315.

15. Hartford, T., and P. H. A. Sneath. 1993. Optical DNA-DNA homology in the genus Listeria. Int. J. Syst. Bacteriol. 43:26-31.

16. Heilmann, K. L., and F. Borchard. 1991. Gastritis due to spiral shaped bacteria other than Helicobacter pylori: clinical, histological and ultrastructural findings. Gut 32:137-140.

17. Henry, G. A., P. H. Long, J. L. Burns, and D. L. Charbonneau. 1987. Gastric spirillosis in beagles. Am. J. Vet. Res. 48:831-836.

18. Huss, V. A. R., H. Festl, and K. H. Schleifer. 1983. Studies on the spectrophotometric determination of DNA hybridization from renaturation rates. Syst. Appl. Microbiol. 4:184-192.

19. Jukes, T. H., and C. R. Cantor. 1969. Evolution of protein molecules, p. 21-132. In H. N. Munro (ed.), Mammalian protein metabolism, vol. 3. Academic Press, Inc., New York, N.Y.

20. Kirkbride, C. A., C. E. Gates, J. E. Collins, and A. E. Ritchie. 1985. Ovine abortion associated with an anaerobic bacterium. J. Am. Vet. Med. Assoc. 186: 789-791.

21. Lee, A., S. L. Hazell, J. O'Rourke, and S. Kouprach. 1988. Isolation of a spiral-shaped bacterium from the cat stomach. Infect. Immun. 56:28432850 .

22. Lockard, V. G., and R. K. Boler. 1970. Ultrastructure of a spiraled microorganism in the gastric mucosa of dogs. Am. J. Vet. Res. 31:1453-1462.

23. Mendes, E. N., D. M. M. Queiroz, F. E. Dewhirst, B. J. Paster, S. B. Moura, and J. G. Fox. 1996. Helicobacter trogontum sp. nov., isolated from the rat intestine. Int. J. Syst. Bacteriol. 46:916-921.

24. On, S. L. W. 1996 . Identification methods for campylobacters, helicobacters and related organisms. Clin. Microbiol. Rev. 9:405-422

25. Paster, B. J., and F. E. Dewhirst. 1988. Phylogeny of campylobacters, wolinellas, Bacteroides gracilis, and Bacteroides ureolyticus by $16 \mathrm{~S}$ ribosomal ribonucleic acid sequencing. Int. J. Syst. Bacteriol. 38:56-62.

26. Paster, B. J., A. Lee, J. G. Fox, F. E. Dewhirst, L. A. Tordoff, G. J. Fraser, J. L. O'Rourke, N. S. Taylor, and R. Ferrero. 1991. Phylogeny of Helicobacter felis sp. nov., Helicobacter mustelae, and related bacteria. Int. J. Syst. Bacteriol. 41:31-38.

27. Pitcher, D. G., N. A. Saunders, and R. J. Owen. 1989. Rapid extraction of bacterial genomic DNA with guanidium thiocyanate. Lett. Appl. Microbiol. 8:151-156.

28. Queiroz, D. M. M., G. A. Rocha, E. N. Mendes, A. P. Lage, A. C. T. Carvalho, and A. J. A. Barbosa. 1990. A spiral microorganism in the stomach of pigs. Vet. Microbiol. 24:199-204.

29. Rappin, G. 1881. Contribution à l'étude des bactéries de la bouche à létat 
normal et dans la fièvre typhoide. Ph.D. Thesis. Collège de France, Nantes.

30. Saitou, N., and M. Nei. 1987. The neighbor-joining method: a new method for reconstructing phylogenetic trees. Mol. Biol. Evol. 4:406-425.

31. Salomon; H. 1898. Ueber das Spirillum des Säugetiermagens und sein Verhalten zu den Belegzellen. Zentralbl. Bakteriol. Parasitenkd. Infektionskr. Hyg. Orig. Abt: 1 19:433-442.

32. Solnick, J. V., J. O'Rourke, A. Lee, B. J. Paster, F. E. Dewhirst, and L. S. Tompkins. 1993. An uncultured gastric spiral organism is a newly identified Helicobacter in humans. J. Infect. Dis. 168:379-385.

33. Stackebrandt, E., and B. M. Goebel. 1994. Taxonomic note: a place for DNA-DNA reassociation and 16S rRNA sequence analysis in the present species definition in bacteriology. Int. J. Syst. Bacteriol. 44:846-849.

34. Ursing, J. B., H. Lior, and R. J. Owen. 1994. Proposal of minimal stan- dards for describing new species of the family Campylobacteraceae. Int. J. Syst. Bacteriol. 44:842-845.

35. Vandamme, P., E. Falsen, R. Rossau, B. Hoste, P. Segers, R. Tytgat, and J. De Ley. 1991. Revision of Campylobacter, Helicobacter, and Wolinella taxonomy: emendation of generic descriptions and proposal of Arcobacter gen. nov. Int. J. Syst. Bacteriol. 41:88-103.

36. Warren, J. R., and B. J. Marshall. 1983. Unidentified curved bacilli on gastric epithelium in active chronic gastritis. Lancet i:1273-1275.

37. Weber, A. F., and E. F. Schmittdiel. 1962. Electron microscopic and bacteriologic studies of spirilla isolated from the fundic stomachs of cats and dogs. Am. J. Vet. Res. 23:422-427.

38. Wu, H., E. Pelkonen, S. Knuutila, and M. Kaartinen. 1995. A human follicular lymphoma B cell line hypermutates its functional immunoglobulin genes in vitro. Eur. J. Immunol. 25:3263-3269. 